\title{
PROCESSING OF CRUDE MINERAL OILS AS EMULSIFABLE CONCENTRATES FORMULATION TO EVALUATE THEIR PHYSICAL PROPERTIES AND PESTICIDAL EFFICIENCY \\ EI-Shiekh, Y. W. A. ${ }^{1}$ and Shereifa, A. E. N. El-Shereif ${ }^{2}$ \\ ${ }^{1}$ Dept. of Pesticides Formulation Res., ${ }^{2}$ Dept. of Bioassay Research, Central Agricultural Pesticides Laboratory, Agric. Res. Center, Dokki, Egypt.
}

\begin{abstract}
Three trade mineral oils $B . W$ and $Y$ were formulated as emulsifable concentrates in percentages of 94,95 and 85 , respectively. The physical properties of the mineral oils used indicated that, $Y 85 \%$ EC mineral oil was the best one because it was more viscous, acidic and, its density and specific gravity were more than the other mineral oils. Also, the spray solutions of $Y(85 \% \mathrm{EC})$ mineral oil for soft and hard waters were more effective than the other spray solutions of B $94 \%$ and $W$ 95\% EC mineral oils. The three mineral oils were evaluated against the adults of Aphis fabae and Tetranychus urticae under laboratory conditions, comparing with $\mathrm{Kz}$ oil "mineral oil" as control oil. The results indicate that the Y $85 \%$ EC exhibited that highest levels of relative toxicity (94.26) fold against $A$. fabae. The results of the tested mineral oil against the T. urticae showed very low level of R.T. Y $85 \%$ EC (8.31) fold, B 94\% EC (2.49) fold and Kz 95\% EC gave (47.47) fold. $Y 85 \%$ EC showed the most effect against laboratory strain of $A$. fabae, followed by B $94 \%$ EC. Results indicated that the mineral oil Kz 95\% was the best efficient against $T$. urticae. Keywords: Emulsifable concentrates, formulation, chlorinated paraffin oil, aphids, red mite.
\end{abstract}

\section{INTRODUCTION}

Modern use of petroleum-derived oils as agricultural crop protectants dates back to the 1800 s, but it was not until the latter half of the 20th century that advances in petroleum chemistry allowed substantial modification and diversification in their commercial applicability.

Petroleum oils have been in use as crop protectants for over a hundred years, and their history has covered a remarkably broad range of developments concerning every aspect from geographic origin and chemical purification to techniques of emulsification and combination with other crop spray materials.

Advances in petroleum chemistry over the past 40 years have minimized the importance of the source of the crude and the influence this once had on its gross composition or base, the relative quantities of the various compounds present, and certain of its resulting chemical and physical properties such as viscosity and boiling point. 
Mineral oils are ideally suited for use alone or in integrated control programs because they are safe to use and environmentally acceptable and have limited residual activity. They are also inexpensive compared to most broad spectrum pesticides and other alternatives. Their use is sustainable because pests are highly unlikely to become resistant. Although oils were once limited to early-season or dormant sprays in the interest of avoiding oil injury to green plant tissue, newer, highly refined horticultural mineral oils (HMOs; also called petroleum spray oils) and agricultural mineral oils (AMOs; broad-range petroleum spray oils) are seeing more recognition of their usefulness in and compatibility with modern pest management approaches (Agnello,2002).

Chlorinated paraffins (CPs), as technical mixtures of polychlorinated alkanes (PCAs), have been produced since the 1930s for use as additives in lubricants and cutting oils as reported by Barber et al., 2005; Peters et al., 2000. PCAs are chlorinated linear chain alkanes with the general formula $\mathrm{C}_{x} \mathrm{H}_{(2 x+2)-y} \mathrm{Cl}_{y}$. They are produced by the chlorination of different $n$-alkane fractions derived from petroleum distillation. The industrial formulations of PCAs are also known as chlorinated paraffins (CPs). They are divided into three groups: short-chain CPs (noted as SCCPs or SPCAs in the literature) comprising 10 to 13 carbon atoms, medium-chain CPs (MCCPs or mPCAs) comprising 14 to 17 carbon atoms and long-chain CPs (LCCPs) with more than 18 or more carbon atoms. The many possible positions for the chlorine atoms and presence of chiral carbon atoms lead to a large number of potential positional isomers, and enantiomers and diastereoisomers. For example, there are theoretically 122161 positional isomers for MCCPs, based on the assumption that no more than one chlorine atom binds to any carbon atom (Government of Canada, 2004). The level of chlorination of CPs varies between $30 \%$ and $72 \%$ by weight (Tomy et al., 1999a).

CPs are viscous colourless or yellowish dense oils. The chemical and physical properties of chlorinated paraffins are determined by the carbon chain length of the paraffin and its chlorine content. Increases in the carbon chain length and chlorination degree of particular paraffin increase the viscosity and density but reduce the volatility (Hardie, 1964). They are also practically insoluble in lower alcohols, glycerol and glycols, but are soluble in chlorinated solvents, aromatic hydrocarbons, ketones, esters, ethers, mineral oils and some cutting oils. They are moderately soluble in unchlorinated aliphatic hydrocarbons (Houghton, 1993).

\section{MATERIALS AND METHODS}

\section{Materials:}

\section{I.1. Experimental Oils:}

The mineral oil crudes $\mathrm{B}$ and $\mathrm{W}$ were attained from Al-Ameria Co. for Petroleum oil distillation and Helb Co. for Pesticides and Chemicals, respectively. While the crude of chlorinated paraffin mineral oil $(\mathrm{Y})$ was processed by Petroleum Research Institute. The reference sample (Kz Oil 95\% EC) was brought from Kafr El-Zayat Co. for Pesticides and Chemicals. 
I.2. Emulsifiers:

Different ionic and non-ionic surfactants used in preparation of the mineral oil formulations were brought from the Egyptian local market.

I.3. Solvents:

Different non-polar solvents in ratio up to $5 \%$ were used for preparation of the used mineral oil crudes emulsifable concentrate.

1.4. Insect Strain:

The laboratory strain of $A$. fabae reared on faba bean seedling in the laboratory at $18{ }^{\circ} \mathrm{C}$ and $90 \% \mathrm{RH}$, this strain were reared in laboratory without exposure to any insecticides and considered as a (laboratory strain).

1.5. Red Mite strain:

The laboratory mite colony Tetranyekus uriticae were reared on cotton seedling in the laboratory at $25^{\circ} \mathrm{C}$ and $90 \% \mathrm{RH}$.

II. Methods:

II.1. Preparation of emulsifable concentrates (EC) mineral oils:

The crude mineral oils $B, W$ and $Y$ in different volumes were mixed with a proper solvent (non polar). Blind of (ionic and non ionic) surfactants were mixed together in different ratios, and then added to previously stirred mineral oils with solvent at $60{ }^{\circ} \mathrm{C}$. The mixture was stirred for $1 \mathrm{~h}$ at the proper temperature. Finally, the formulations of the prepared mineral oils $\mathrm{W}$ $95 \%$, B 94\% and Y 85\% emulsifable concentrates (EC) were kept cool and then their properties were estimated.

\section{II.2.Physical Studies:}

II.2.1. Physical properties of the crude oils:

The physical properties of crude mineral oil samples were carried out according to American Society of Testing and Materials (ASTM) to detect density \& specific gravity (D 1217-93), distillation point (D 86-99), Unsulfonated Residue (D 483-97), surface tension (D 1331-89:2001), refractive index (D 1747-99), viscosity (D 2196-2005), flash point (D 932008) and pour point (D 2386-97) (ASTM 93, 97, 99, 2001, 2005 and 2008, respectively).

\section{II.2.2. Physical properties of the EC formulated mineral oils:}

The prepared crude oil formulations were stored at $54 \pm 1^{\circ} \mathrm{C}$ for $3 \& 14$ days (MT 46.1.3) and other at $0{ }^{\circ} \mathrm{C}$ for 7 days (Dobrat and Martijn, 1995). The physical properties of the EC formulated mineral oil samples (initially, and after cold and hot storage) were carried out according to CIPAC handbook for detecting free acidity/ or alkalinity (MT 191) (Dobrat and Martijn, 2005), density and specific gravity (MT 3.1) (Dobrat and Martijn, 1995). Also, surface tension (D 1331-89:2001), refractive index (D 1218-2002), viscosity (D 2196-2005) and flash point (D 93-2008) were carried out according to American Society of Testing and Materials (ASTM 2001, 2002, 2005 and 2008).

II.2.3. Physical properties of the spray solution of EC formulated mineral oils:

The spray solutions of EC formulated mineral oil physical properties under dilution rate $5 \%$ for both soft and hard water were carried out according to CIPAC handbook to detect persistent foam (MT 47.2), emulsion stability 
(MT 36.3), pH (MT 75.3), and conductivity (MT 32) (Dobrat and Martijn, 1995). Also, surface tension (D 1331-89:2001), refractive index (D 12182002), viscosity (D 2196-2005) and flash point (D 93-2008) were carried out according to American Society of Testing and Materials (ASTM 2001, 2002, 2005 and 2008).

\section{II.3. Testing and evaluation the Aphicidal efficiency:}

The three mineral oils at six concentrations and in addition of Mineral $\mathrm{Kz}$ oil, at concentrations of $9500,4750,2375,1187.5,593.75$ and 148.44 ppm were tested against the adults of Aphid fabae according to the following method:

A stock solution of each tested compound was prepared and subsequent serial concentrations were made by diluting with water $(\mathrm{v} / \mathrm{v})$ to give the necessary concentration to give about $20 \%-80 \%$ mortality of each material. The faba bean leaves were dipped in the insecticidal prepared solution for a period of 20 seconds then left for complete dryness on paper towel, then placed upside down on agar bed in small Petri dish $(60 \mathrm{~mm}$ diameter). Ten healthy apterous adults were placed on the treated leaves surface of each Petri dish while leaves dipped in tap water were used as control. Five replicate batches of aphides (i.e. 50 insects) were used per each concentration; serial concentrations were used for each compound. Petri dishes containing aphids were carefully closed and kept in conditioned room for $18{ }^{\circ} \mathrm{C}$ and $90 \% \mathrm{RH}$ for a period of 24 hours. The mortality percentages were corrected according to (Abbott, 1925).

\section{II.4. Acaricidal efficiency:}

The three mineral oils at six concentrations and in addition of Mineral Kz oil, at concentrations $(9500,4750,2375,1187.5,593.75$ and 148.44 ppm) were tested against the adult female of red mite according to the following method:

Discs of cotton plant leaves with 3 centimeters diameter were dipped in each concentration for 20 seconds the discs were placed on wet cotton in petri dishes contained moisten cotton, to prevent mite's escape and left to dry while the untreated check control leaves were dipped in water. Ten mite female adults were placed on each concentration were replicated three times (Moustafa et al., 2002). The percentage mortality was calculated after 24 hours. The corrected percent moralities were statistically computed according to Finney, (1971).

\section{RESULTS AND DISCUSSION}

\section{(A) Physical parameters:}

The physical properties of the three crude mineral oils were studied according to ASTM protocols (93, 97, 99, 2001, 2005 and 2008, respectively) to evaluate their natures. The data presented in table (1) illustrated the physical properties of the 3 crude oils $B, W$ and $Y$. The crude mineral oils of $B$ and $\mathrm{W}$ are saturated hydrocarbon mineral oils where $\mathrm{Y}$ oil is chlorinated paraffins. 
The unsulfonated residues (UR) for mineral oils $B$ and $W$ were 94 and $95 \%$, respectively where UR value of $Y$ oil was $98 \%$. The distillation properties of the mineral oils were acceptable because the distillation range of 3 mineral oils between $10 \%$ and $90 \%$ of their values were 22 to $32{ }^{\circ} \mathrm{C}$.

Also, the pour points of the mineral oils were $-20,-23$ and $-28{ }^{\circ} \mathrm{C}$ for $\mathrm{B}, \mathrm{W}$ and $\mathrm{Y}$, respectively. The density of the chlorinated paraffins was 1.112 $\mathrm{gm} / \mathrm{cm}^{3}$ (more than the density of water), while it was $0.845 \mathrm{gm} / \mathrm{cm}^{3}$ for the other two mineral oils. Also, the specific gravity of the chlorinated paraffins was 1.085 , while it was 0.815 and 0.77 for $B$ and $W$ mineral oils, respectively.

The all tested mineral oils were transparent and their refractive indexes were $1.4671,1.4680$ and 1.4913 for the oils $B, W$ and $Y$, respectively. The viscous properties of the mineral oils appeared that $Y$ was more viscous than the other mineral oils where their viscosities were 116.68 , 21.68 and $22.8 \mathrm{cp}$, respectively. Also, the mineral oils surface tensions were in the range $32-38$ dyne $/ \mathrm{cm}$.

The flash points of the three crude mineral oils were acceptable because it was over $75^{\circ} \mathrm{C}$ for all the crude mineral oils $\mathrm{B}, \mathrm{W}$ and $\mathrm{Y}$.

Table (1): Physical properties of crude mineral oils at $25^{\circ} \mathrm{C}$ according to ASTM protocols

\begin{tabular}{|c|c|c|c|}
\hline ASTM test & B & $\mathbf{W}$ & $\mathbf{Y}$ \\
\hline Viscosity (cp.) & 21.69 & 22.86 & 116.58 \\
\hline Surface tension (dyne/cm) & 32.9 & 32.8 & 37.8 \\
\hline Density $\left(\mathrm{gm} / \mathrm{cm}^{3}\right)$ & 0.845 & 0.845 & 1.112 \\
\hline Refractive index & 1.4671 & 1.4680 & 1.4913 \\
\hline Specific gravity & 0.815 & 0.770 & 1.085 \\
\hline $10 \%$ & 338 & 336 & 310 \\
\hline Distillation point $\left({ }^{\circ} \mathrm{C}\right) \quad 50 \%$ & 355 & 356 & 328 \\
\hline $90 \%$ & 360 & 368 & 342 \\
\hline Pour point $\left({ }^{\circ} \mathrm{C}\right)$ & -20 & -23 & -28 \\
\hline Flash Point $\left({ }^{\circ} \mathrm{C}\right)$ & Over 75 & Over 75 & Over 75 \\
\hline UR. Value (\%) & 94 & 95 & 98 \\
\hline
\end{tabular}

The mineral oils were formulated as emulsifable concentrates (EC) which W was $95 \%$, Y $85 \%$ and B $94 \%$ as a percent of the crude oils in the formulations. Their physical properties were measured initially, cold storage at $0{ }^{\circ} \mathrm{C}$ for 7 days and accelerated hot storage at $54^{\circ} \mathrm{C}$ for 3 and 14 days respectively with reference to the KZ 95\% EC mineral oil (table 2) according to Anonymous (2006).

It means that, the chlorinated paraffins $Y$ will be lower layer when mixed with water and vice versa. Also, the two other oils $(B, W)$ will be the upper layer when mixed with water. The present results in table (2) indicated that, $Y$ mineral oil will be more effective oil than the other two mineral oils $B$ and $\mathrm{W}$ because it was more viscous and stable. Theses data were in agreement with those suggested by Tawfik and El-Sisi, 1987.

The physical parameters: free acidity, density, specific gravity, viscosity, surface tension and refractive index of the four EC mineral oils were measured. The data in table (2) illustrated comparative studies of their physical parameters. 
Generally, the cold and hot storage did not affect on the refractive index of the mineral oils. Also, density and specific gravity of $\mathrm{W}, \mathrm{B}$ and $\mathrm{Kz}$ mineral oils were in range of 0.84 to $0.88 \mathrm{gm} / \mathrm{cm}^{3}$ where the density and the specific gravity of $Y$ oil were in the range of 1.10 to $1.12 \mathrm{gm} / \mathrm{cm}^{3}$ The $Y$ mineral oil was more acidic in nature than the other 3 mineral oils, where their acidity were $0.74,0.26,0.24$ and 0.19 as $\%$ of $\mathrm{H}_{2} \mathrm{SO}_{4}$ for $\mathrm{Y}, \mathrm{W}$ and $\mathrm{B}$ EC mineral oils, respectively. The importance of free acidity referred to the alkaline nature of spray dilution water which makes neutralization with it.

The $Y$ mineral oil was more viscous than the other 3 mineral oils where its viscosity was approximately 7 times of the viscosity of $\mathrm{W}, \mathrm{B}$ and $\mathrm{Kz}$ EC mineral oils. Average values of $167.58,24.02,22.40$ and 21.54 for $Y, K z$, $\mathrm{W}$ and $\mathrm{B} E C$ mineral oils formulation were found for these oils, respectively. The adhering of the mineral oil on the surface of leaf depending on its viscosity whereas, the viscosity increase the adhering properties increase.

The surface tensions of the four mineral oils were varied in the range $34 \pm 4$ dyne/cm during the different types of storage. Also, the flash points of the formulated mineral oils were determined, where it were more than $75^{\circ} \mathrm{C}$ for the evaluated samples. The present results suggested that, Y $85 \%$ EC mineral oil was the best one according to its physical properties followed by Kz 95\% EC, W 95\% EC and B94\% EC.

The physico-chemical properties of spray solution (soft and hard water) under dilution rate $5 \%$ for the mineral oils of W 95\%, Y $85 \%$, B $94 \%$ and $\mathrm{Kz} 95 \%$ EC were measured. The data presented in table (3), showed their physico-chemical properties which were measured according to Dobrat and Martijn, 1995 and 2005.

The persistent foam of the eight samples soft and hard water of the corresponding mineral oil were acceptable where the highest volume was 8 $\mathrm{ml}$ in hard water of $\mathrm{Y} 85 \% \mathrm{EC}$ oil while the lowest value was $1 \mathrm{ml}$ of soft water in W 95\% EC mineral oil. All the soft and hard water samples were passed the emulsion stability test where there weren't any types of separation happened during 30 minutes.

The viscosity of spray solution samples of the mineral oils W $95 \%$, B $94 \%$ and $\mathrm{Kz} 95 \% \mathrm{EC}$ were varied in the range (2.17 to $2.24 \mathrm{cp}$ ), where the spray solution of $Y 85 \%$ EC mineral oil have the highest viscosity (2.4 and $2.22 \mathrm{cp}$ ) for soft and hard water, respectively. Also, the surface tensions of the samples were varied in the range of 35.2 to $39.6 \mathrm{dyne} / \mathrm{cm}$. 
J. Plant Prot. and Pathology, Mansoura Univ., Vol. 2 (5), May, 2011 2 
The acidic nature of crude and formulated mineral oil $Y$ appeared its acidity compared with the other mineral oil W, B and Kz oil. Soft and hard water spray solutions of $Y$ oil were the highest acidic sample between the all samples where their values were 4.33 and $4.81 \%$ as $\mathrm{H}_{2} \mathrm{SO}_{4}$.

Conductivity and salinity and total dissolved salts T.D.S. are directly proportional to each other. The soft and hard water spray solutions of $Y$ mineral oil have the highest values of conductivity, salinity and T.D.S, and they were $(216$ and $758 \mu \mathrm{s}),(0.1$ and $0.4 \%$ ) and (103 and $363 \mathrm{mg} / \mathrm{l})$, respectively.

Physical and chemical properties of spray solutions predict us that, the $Y$ 85\% EC mineral oil will be more efficient than the other oils (Moustafa et al., 1990).

Table (3): Physical Properties of Spray solutions of Prepared EC Formulations

\begin{tabular}{|l|c|c|c|c|c|c|c|c|}
\hline \multirow{2}{*}{$\begin{array}{l}\text { Formulations } \\
\text { used }\end{array}$} & \multicolumn{2}{|c|}{ W 95\% EC } & \multicolumn{2}{c|}{ Y 85\% EC } & \multicolumn{2}{c|}{ B 94\% EC } & \multicolumn{2}{c|}{ KZ 95 \%EC } \\
\cline { 2 - 9 } & $\begin{array}{c}\text { Soft } \\
\text { water }\end{array}$ & $\begin{array}{c}\text { Hard } \\
\text { Water }\end{array}$ & $\begin{array}{c}\text { Soft } \\
\text { water }\end{array}$ & $\begin{array}{c}\text { Hard } \\
\text { Water }\end{array}$ & $\begin{array}{c}\text { Soft } \\
\text { water }\end{array}$ & $\begin{array}{c}\text { Hard } \\
\text { Water }\end{array}$ & $\begin{array}{c}\text { Soft } \\
\text { water }\end{array}$ & $\begin{array}{c}\text { Hard } \\
\text { Water }\end{array}$ \\
\hline $\begin{array}{l}\text { Foaming } \\
\text { (mm) }\end{array}$ & 2 & 5 & 10 & 10 & 3 & 3 & 6 & 2 \\
\hline $\begin{array}{l}\text { Emulsion } \\
\text { Stability }\end{array}$ & Pass & Pass & Pass & Pass & Pass & Pass & Pass & Pass \\
\hline $\begin{array}{l}\text { Viscosity } \\
(\mathrm{cp} .)\end{array}$ & 2.18 & 2.18 & 2.24 & 2.22 & 2.18 & 2.17 & 2.18 & 2.21 \\
\hline $\begin{array}{l}\text { Surface } \\
\begin{array}{l}\text { Tension } \\
\text { (dyne/cm) }\end{array}\end{array}$ & 39.6 & 36.41 & 38.63 & 39.6 & & & 39.2 & 35.2 \\
\hline pH & 4.83 & 5.60 & 4.33 & 4.81 & 4.59 & 4.49 & 6.02 & 5.76 \\
\hline $\begin{array}{l}\text { Conductivity } \\
(\mu \mathrm{s})\end{array}$ & 136.1 & 682 & 216 & 758 & 141.7 & 684 & 154.1 & 712 \\
\hline $\begin{array}{l}\text { Salinity } \\
(\%)\end{array}$ & 0.1 & 0.3 & 0.1 & 0.4 & 0.1 & 0.3 & 0.1 & 0.3 \\
\hline $\begin{array}{l}\text { T.D.S } \\
(\mathrm{mg} / \mathrm{l})\end{array}$ & 65 & 326 & 103 & 363 & 66 & 327 & 73 & 340 \\
\hline
\end{tabular}

(B) Laboratory bioassays:

The toxicity of the experimental mineral oils against the adult of laboratory stain of Aphis fabae is summarized in table (4). The relative toxicity (R.T.) was calculated from LC $_{50}$ values by assigning and arbitrary value of 1 for the least effective compound. Based on the LC $_{50}$ values shown in table (4), the results indicate that the $Y 85 \% \mathrm{EC}$ have the highest levels of relative toxicity (93.25) followed by B $94 \%$ EC, while its relative toxicity is 41.93 fold.

Data in table (5) indicated that the increasing of ppm concentrations of tested oils revealed in increasing in the adult female of red mite morality.

Also, table (5) shows that Kz 95\% EC oil was the most effective compound against Tetranychus urticae, while W 95\% EC was the least active 
one toxicity value R.T. was (2.49) fold. The $L_{50}$ and relative toxicity for $Y$ $85 \% \mathrm{EC}\left(\mathrm{LC}_{50}-5616.45 \mathrm{ppm}\right)$ relative toxicity value was 8.31 fold.

The results were agreed with that obtained by Mostafa et al., (2002). They studied the efficiency of three types of oils against Aphis fabae and Tetranychus urticae. All candidate oils exhibited $100 \%$ mortality against aphids adults after 24 hours from treatment at the concentration of 200, 100 and $50 \mathrm{ppm}$.

Complete inhibition of egg hatchability of the red mite Tetranychus urticae was obtained at 200 and 100 ppm for all the tested oils.

It may be concluded that the mineral oils can be considered as significant compounds for crop production management. They have distinct advantages over broad spectrum pesticides cause little or no damage to beneficial insects and mite. Pests are unlikely to develop resistance against them.

Table (4): Toxicity of different mineral oils (EC formulations) against the adults of laboratory strain of Aphis fabae after 24 hours treatment.

\begin{tabular}{|l|c|c|c|c|c|c|c|}
\hline $\begin{array}{l}\text { Formulated } \\
\text { mineral oils }\end{array}$ & $\mathbf{L C}_{10}$ & $\mathbf{L C}_{25}$ & $\mathbf{L C}_{50}$ & $\mathbf{L C}_{90}$ & Slope & $\begin{array}{l}\text { Relative } \\
\text { Toxicity }\end{array}$ & $\begin{array}{l}\text { Toxicity } \\
\text { Index }\end{array}$ \\
\hline W 95\% & $1.8 \times 10^{14}$ & $2.9 \times 10^{28}$ & $1.7 \times 10^{44}$ & $1.6 \times 10^{\prime \prime}$ & 0.04 & $\approx 0$ & $\approx 0$ \\
\hline Y 85\% & 60.92 & 252.8 & 1229 & 24795 & 0.98 & 94.26 & 100 \\
\hline B 94\% & 298.5 & 852.2 & 2733.4 & 25081 & 1.33 & 42.38 & 44.97 \\
\hline KZ 95\% & 156.5 & 3578.95 & 115840.5 & $8.5 \times 10^{\prime}$ & 0.45 & 1 & 1.71 \\
\hline
\end{tabular}

Table (5): Toxicity of different mineral oils (EC formulations) against the laboratory adults of strain of Tetrnychus urticae after 24 hours treatment.

\begin{tabular}{|l|c|c|c|c|c|c|c|}
\hline $\begin{array}{l}\text { Formulated } \\
\text { mineral oils }\end{array}$ & $\mathbf{L C}_{10}$ & $\mathbf{L C}_{\mathbf{2 5}}$ & LC $_{\mathbf{5 0}}$ & LC $_{\mathbf{9 0}}$ & Slope & $\begin{array}{l}\text { Relative } \\
\text { Toxicity }\end{array}$ & $\begin{array}{c}\text { Toxicity } \\
\text { Index }\end{array}$ \\
\hline W 95\% & 969.88 & 6076.49 & 46672.63 & 2245979 & 0.762 & 1 & 2.11 \\
\hline Y 85\% & 520.37 & 1605.91 & 5616.45 & 60619 & 1.241 & 8.31 & 17.51 \\
\hline B 94\% & 558.12 & 2944.62 & 18686.18 & 6256234 & 0.841 & 2.49 & 5.26 \\
\hline KZ 95\% & 77.56 & 258.30 & 983.16 & 12463 & 1.162 & 47.47 & 100 \\
\hline
\end{tabular}

Relative Toxicity $=$ No. of folds comparing with W 95\% EC. 
El-Shiekh, Y. W. A. and Shereifa, A. E. N. El-Shereif 
Figure (1): Ldp lines of the formulated mineral oils against (A) Aphis fabae and (B) Tetrnychus urticae

\section{REFERENCES}

Abbott, W. S. (1925). A method for computing the effectiveness of an insecticide. J. Entomol., $166-267$.

Agnello, A. (2002). Petroleum-derived spray oils: chemistry, history, refining and formulation. Pages 2-18 In Beattie, G.A.C., Watson, D.M., Stevens, M., Spooner-Hart, R. and Rae, D.J. (eds). Spray Oils Beyond 2000 Sustainable Pest \& Disease Management. University of Western Sydney.

Anonymous (2006). Pesticides Specifications, prepared by the FAO/ WHO Joint Meeting on Pesticide Specifications (JMPS), pp: 36.

ASTM, (1993). American Society of Testing and Materials, Standard Test Method for Density and Relative Density (Specific Gravity) of Liquids by Bingham Pycnometer, D-1217.

ASTM, (1997). American Society of Testing and Materials, Standard Test Method for Freezing Point of Aviation Fuels, D-2386.

ASTM, (1997). American Society of Testing and Materials, Standard Test Method for Unsulfonated Residue of Petroleum Plant Spray Oils, D483.

ASTM, (1999). American Society of Testing and Materials, Standard Test Method for Refractive Index of Viscous Materials, D-1747.

ASTM, (1999). American Society of Testing and Materials, Standard Test Method for Distillation of Petroleum Products at Atmospheric Pressure, D-86.

ASTM, (2001). American Society of Testing and Materials, Standard Test Method for Surface and Interfacial Tension of Solution of SurfaceActive Agents, D-1331.

ASTM, (2002). American Society of Testing and Materials, Standard Test Method for Refractive Index and Refractive Dispersion of Hydrocarbon Liquids, D-1218.

ASTM, (2005). American Society of Testing and Materials, Standard Test Method for Rheological Properties of Non-Newtonian Materials by Rotational (Brookfield type) Viscometer, D-2196.

ASTM, (2008). American Society of Testing and Materials, Standard Test Methods for Flash Point by Pensky-Martens Closed Cup Tester, D-93.

Barber J. L.; Sweetman A.; Thomas G. O.; Braekvelt E. and Jones K. C. (2005). Spatial and temporal variability in air concentrations of shortchain (C10-C13) and medium-chain (C14-C17) chlorinated n-alkanes measured in the U.K. atmosphere. Environ Sci Technol;39:4407-15.

Dobrat, W. and A. Martijn, (1995). CIPAC Hand Book, Volumes F. MT 3.1, MT 31.2, MT 32, MT 36.2, MT 47.2 and MT 75. Pp: 11-12; 98; 103; $112-114 ; 152-153 ; 205-206$.

Dobrat, W. and A. Martijn, (2005). CIPAC Hand Book, Volumes J. MT 191. Pp: 143-144. 
Finney, D.J. (1971). Probit Analysis ( $3^{\text {rd }}$ Ed.) Cambrige Univ. Press, London. Government of Canada, E.C. Draft PSL1 Follow-up Report on Chlorinated Paraffins, (2004).

Hardie, D. W. F. (1964). Chlorocarbons and chlorohydrocarbons: Chlorinated paraffins. In: Kirk-Othmer encyclopedia of chemical technology. New York, John Wiley and Sons, vol 5, pp 231-240.

Houghton, K. L. (1993) Chlorinated paraffins. In: In: Kirk-Othmer encyclopedia of chemical technology. New York, John Wiley and Sons,vol 6, pp 78-87.

Moustafa, O. K.; Z. M. El-Attal and A. G. El-Sisi, (1990). Influence physicochemical properties of water on the performance and efficiency some insecticides. Agric. Res. Rev., Egypt P. $127-133$.

Moustafa, O. K.; Hala, M. Abou-Yousef and Z. M. El-Attal (2002). Efficiency of three types of oils against Aphis fabae and Tetranychus urticae. Egypt. J. Agric. Res.: 80(3): 1133 - 1141.

Peters, A. J.; Tomy, G. T.; Jones, K. C.; Coleman, P. and Stern, G. A. (2000). Occurrence of $\mathrm{C} 10-\mathrm{C} 13$ polychlorinated n-alkanes in the atmosphere of the United Kingdom. Atmos Environ; 34:3085-90.

Tawfik, Mona H. and A. G. El-Sisi, (1987). Persistent of foliar fertilizers on the physical properties and insecticidal activity of locally spray oils against the scale insect Parlatoria ziziphus (Lucas) Naf. Conference of Pests \& Diseases of Vegetables \& Orchard, Ismaillia, Egypt, Pp. 376

Tomy, G. T.; Stern, G. A.; Lockhart, W. L.; Muir, D. C. G. (1999a). Occurrence of C10-C13 polychlorinated n-alkanes in Canadian midlatitude and Arctic lake sediments. Environ Sci. Technol. 33:2858-63.

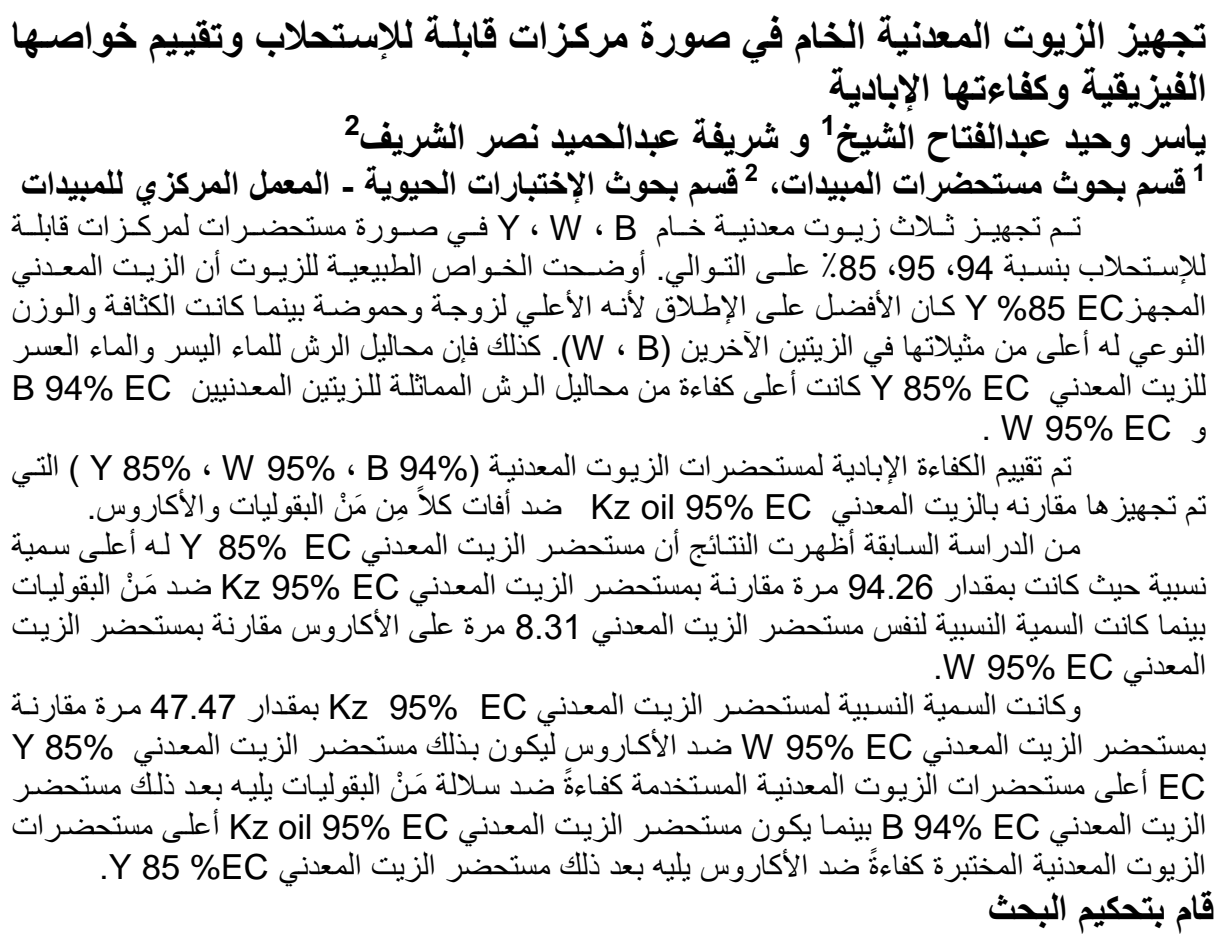


J. Plant Prot. and Pathology, Mansoura Univ., Vol. 2 (5), May, 2011

كلية الزراعة - جامعة المنصورة

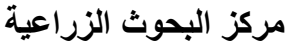

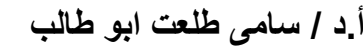

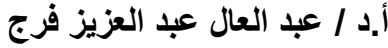


El-Shiekh, Y. W. A. and Shereifa, A. E. N. El-Shereif 
Table (2): Physical properties of the EC mineral oils under different storage types.

\begin{tabular}{|c|c|c|c|c|c|c|c|c|c|c|c|c|c|c|c|c|}
\hline Mineral oils & \multicolumn{4}{|c|}{ W 95\%EC } & \multicolumn{4}{|c|}{ Y 85\%EC } & \multicolumn{4}{|c|}{ B 94\%EC } & \multicolumn{4}{|c|}{ KZ 95\%EC (Ref.) } \\
\hline Type of storage & $\begin{array}{l}\text { Initial } \\
\text { time }\end{array}$ & $\begin{array}{c}0^{\circ} \mathrm{C} \\
\text { For } 7 \\
\text { days } \\
\end{array}$ & $\begin{array}{l}54^{\circ} \mathrm{C} \\
\text { For } 3 \\
\text { days }\end{array}$ & \begin{tabular}{|c|}
$54^{\circ} \mathrm{C}$ \\
For 14 \\
days \\
\end{tabular} & $\begin{array}{c}\text { Initial } \\
\text { time }\end{array}$ & $\begin{array}{c}0^{\circ} \mathrm{C} \\
\text { For } 7 \\
\text { days }\end{array}$ & $\begin{array}{l}54^{\circ} \mathrm{C} \\
\text { For } 3 \\
\text { days } \\
\end{array}$ & \begin{tabular}{|c|}
$54^{\circ} \mathrm{C}$ \\
For 14 \\
days \\
\end{tabular} & $\begin{array}{c}\text { Initial } \\
\text { time }\end{array}$ & $\begin{array}{c}0^{\circ} \mathrm{C} \\
\text { For } 7 \\
\text { days }\end{array}$ & \begin{tabular}{|l|}
$54^{\circ} \mathrm{C}$ \\
For 3 \\
days \\
\end{tabular} & \begin{tabular}{|c|}
$54^{\circ} \mathrm{C}$ \\
For 14 \\
days \\
\end{tabular} & $\begin{array}{c}\text { Initial } \\
\text { time }\end{array}$ & \begin{tabular}{|c|}
$0^{\circ} \mathrm{C}$ \\
For 7 \\
days
\end{tabular} & $\begin{array}{l}54^{\circ} \mathrm{C} \\
\text { For } 3 \\
\text { days }\end{array}$ & $\begin{array}{c}54^{\circ} \mathrm{C} \\
\text { For } 14 \\
\text { days }\end{array}$ \\
\hline \begin{tabular}{|l|} 
Free Acidity \\
$\left(\%\right.$ as $\left.\mathrm{H}_{2} \mathrm{SO}_{4}\right)$
\end{tabular} & 0.26 & 0.0784 & 0.26 & 0.0686 & 0.74 & 0.0588 & 0.90 & 0.049 & 0.24 & 0.0294 & 0.310 & 0.0196 & 0.19 & 0.0196 & 0.240 & 0.0147 \\
\hline \begin{tabular}{|l} 
Density \\
$\left(\mathrm{gm} / \mathrm{cm}^{3}\right)$
\end{tabular} & 0.85 & 0.859 & 0.86 & 0.86 & 1.11 & 1.11 & 1.11 & 1.11 & 0.85 & 0.86 & 0.85 & 0.86 & 0.85 & 0.85 & 0.85 & 0.85 \\
\hline $\begin{array}{l}\text { Specific } \\
\text { Gravity }\end{array}$ & 0.86 & 0.85 & 0.87 & 0.85 & 1.10 & 1.12 & 1.10 & 1.11 & 0.88 & 0.85 & 0.84 & 0.86 & 0.84 & 0.85 & 0.85 & 0.85 \\
\hline $\begin{array}{l}\text { Viscosity } \\
\text { (cp.) } 25^{\circ} \mathrm{C}\end{array}$ & 22.40 & 21.99 & 21.48 & 21.63 & 167.56 & 188.72 & 167.00 & 146.25 & 21.54 & 21.69 & 21.46 & 21.27 & 24.02 & 24.29 & 23.67 & 23.84 \\
\hline $\begin{array}{l}\text { Surface Tension } \\
(\text { dyne/cm) }\end{array}$ & 34.43 & 37.71 & 30.46 & 29.89 & 38.63 & 36.0 & 34.43 & 37.71 & 36.84 & 38.63 & 33.71 & 34.43 & 35.20 & 39.6 & 33.0 & 36.84 \\
\hline Refractive Index & 1.4660 & 1.4656 & 1.4658 & 1.4658 & 1.4934 & 1.4927 & 1.4928 & 1.4928 & 1.4652 & 1.4649 & 1.4652 & 1.4648 & 1.4660 & 1.4660 & 1.4659 & 1.4660 \\
\hline Flash Point & \multicolumn{4}{|c|}{ Over $75^{\circ} \mathrm{C}$} & \multicolumn{4}{|c|}{ Over $75^{\circ} \mathrm{C}$} & \multicolumn{4}{|c|}{ Over $75^{\circ} \mathrm{C}$} & \multicolumn{4}{|c|}{ Over $75^{\circ} \mathrm{C}$} \\
\hline
\end{tabular}

